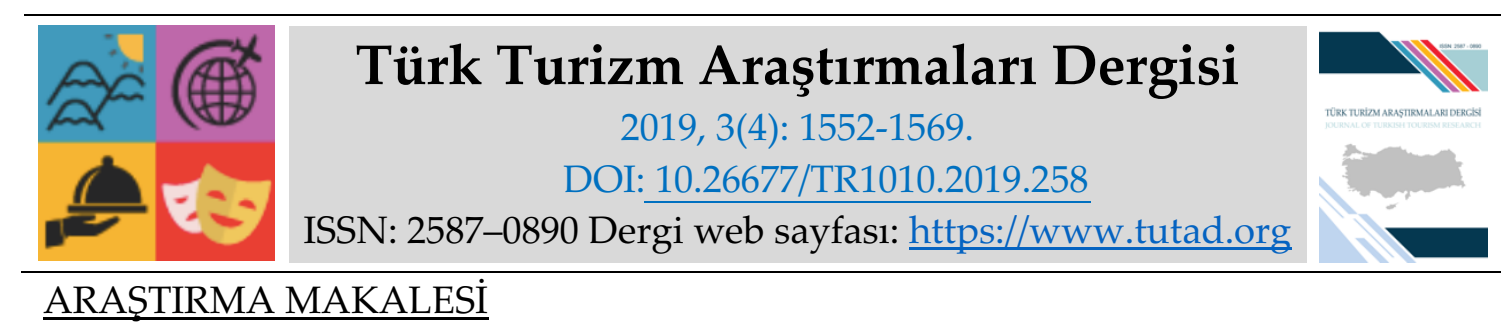

\title{
Bartın'ı Ziyaret Eden Yerli Turistlerin Yöresel Yiyeceklere Yönelik Tutum ve Davranışlarının Belirlenmesi
}

Dr. Öğr. Üyesi Ayhan KARAKAŞ, Bartın Üniversitesi, İktisadi ve İdari Bilimler Fakültesi, Bartın, e-posta: akarakas@bartin.edu.tr ORCID: https://orcid.org/0000-0001-9285-0552

Dr. Öğr. Üyesi Hande UYAR OĞUZ, Bartın Üniversitesi, İktisadi ve İdari Bilimler Fakültesi, Bartın, e-posta: handeuyar@bartin.edu.tr ORCID: https://orcid.org/0000-0001-8322-3864

Öz

Günümüz seyahat davranışları incelendiğinde, turistlerin $3 S$ adı verilen deniz-kum- güneş turizmi dışında alternatif turizme olan ilgilerinin her geçen gün arttığı görülmektedir. Özellikle eğitim ve kültür seviyesi yüksek turistler, kendi yaşam tarzlarından farklı olanı aramakta, bunun için modern teknolojik araçları da kullanarak özgün, kültürel ve yerel özeliklere sahip destinasyonlara seyahatleri tercih etmektedirler. Bu bağlamda yöre ya da destinasyona özgü yöresel yiyecek ve içeceklerin turistler için önemli bir çekicilik unsuru haline geldiği görülmektedir. Bu çalışmanın amacı Bartın'ı ziyaret eden turistlerin yöresel yiyeceklere yönelik tutum ve davranışlarının belirlenmesidir. Bartın İl Kültür ve Turizm Müdürlügü 2017 yılı verileri incelendiğinde, Bartın Il'’ini en fazla ziyaret edenlerin 275.001 geceleme ile yerli turistler olduğu görülmektedir. Dolayısıyla araştırmanın evrenini Bartın'ı ziyaret eden yerli turistler oluşturmaktadır. Örneklemin belirlenmesinde kolayda örnekleme metodu kullanılmıştır. Araştırma kapsamında 397 yerli turist ile anket tekniği kullanılarak yüz yüze uygulanmıştır. Araştırma sonuçları incelendiğinde; Bartın'ı ziyaret eden yerli turistlerin, ziyaret nedenlerinin en başında Bartın yöresel mutfağı olmadığı, Bartın yöresel yemekleri hakkında ne ziyaret öncesi ne de ziyaret sonrası yeterince bilgiye sahip ol(a)madıkları, bundaki en önemli unsurun ise yöre mutfağının gerek İldeki konaklama işletmelerinin gerekse yiyecek-içecek işletmelerinin mönülerinde yer almaması olduğu, ayrıca ziyaretçilere bu lezzetleri tattıracak işletme sayısının az olduğu görülmektedir.

Anahtar Kelimeler: Yöresel Yiyecekler, Yerli Turist, Bartın.

Makale Gönderme Tarihi: 22.06.2019

Makale Kabul Tarihi: 01.10.2019

Önerilen Atıf:

Karakaş, A. ve Uyar Oğuz, H. (2019). Bartın'ı Ziyaret Eden Yerli Turistlerin Yöresel Yiyeceklere Yönelik Tutum ve Davranışlarının Belirlenmesi, Türk Turizm Araştırmaları Dergisi, 3(4): 15521569.

(C) 2019 Türk Turizm Araştırmaları Dergisi. 


\title{
Journal of Turkish Tourism Research
}

2019, 3(4): 1552-1569.

DOI: $10.26677 /$ TR1010.2019.258

ISSN: 2587-0890 Journal Homepage: https://www.tutad.org

\section{$\underline{\text { RESEARCH PAPER }}$}

\section{Determination of Local Tourist's Attitudes and Behaviors Visiting Bartın Province for Local Foods}

Assistant Prof. Dr. Ayhan KARAKAŞ, Bartın University, Faculty of Economics and Administrative Sciences, Bartın, e-mail: akarakas@bartin.edu.tr

ORCID: https://orcid.org/0000-0001-9285-0552

Assistant Prof. Dr. Hande UYAR OĞUZ, Bartın University, Faculty of Economics and Administrative Sciences, Bartın, e-mail: handeuyar@bartin.edu.tr

ORCID: https://orcid.org/0000-0001-8322-3864

\begin{abstract}
When we analysis today's travel behaviors, it has seen that the number of tourists whose interest of alternative tourism except $3 S$ (sea-sand-sun) tourism is increasing day by day. Especially tourists with high education and culture are looking for something different from their own life and for this they also use modern technological tools to travel destinations which have original cultural and local characteristics. In this context, specific local foods and beverages in the region or destination have become an important attraction for tourists. When Bartın Provincial Directorate of Culture and Tourism data of 2017 are examined, it has seen that most of the visitors to Bartın Province were domestic tourists with 275.001 overnight stay. Because of this, the population of this research is composed of domestic tourists and also the convenience sampling method has been used in this research. It has reached 384 local tourists and interviewed with them using the survey technique. Statistical package program was used for the analysis of the data. The research results show us that the first aim of visiting Bartın Province is not the local cuisine for local tourists, they didn't have enough knowledge about regional foods before or after visiting Bartın, The local cuisine is not included in the menu of the food and beverage enterprises is the main reason of why the local tourist are not interested to local cuisine. It also shows that the numbers of establishments that will taste these local foods are not enough in Bartın.
\end{abstract}

Keywords: Local Foods, Domestic Tourists, Bartın.

Received: 22.06.2019

Accepted: 01.10.2019

\section{Suggested Citation:}

Karakaş, A. and Uyar Oğuz, H. (2019). Determination of Local Tourist's Attitudes and Behaviors Visiting Bartın Province for Local Foods, Journal of Turkish Tourism Research, 3(4): 1552-1569.

(C) 2019 Türk Turizm Araştırmaları Dergisi. 


\section{Gíriş}

Turizm, yerel kimliğin öne çıarılmasını mümkün kılan, aynı zamanda kültürel çeşitlilik ve özgünlüğün korunmasını ve bu konuda farkındalığın yaratılmasını sağlayan önemli bir sektördür (Uslu ve Kiper, 2006:307). Bununla birlikte son dönemlerde bir destinasyonun sahip olduğu kendine özgü yöresel ürünler de turizm bölgesi seçilmesinde önemli hale gelmiştir. (Bezirgan ve Koç, 2014:918). Literatür incelendiğinde son 10 yıldır yerel yiyeceklerin turizmdeki önemine dair konuların fazlaca işlendiği görülmektedir (Kim ve Eves, 2012).

Yöresel yiyecekler, kırsalda ya da şehir merkezlerindeki üretimi dünden bugüne aktarılmış, bayram, dügün gibi özel günlerde daha çok tüketilen, mutfak kültürüne yerleşmiş ve yerel halk tarafından diğer yemeklerden daha üstün tutulan yiyeceklerdir (Hatipoğlu vd., 2013:7). Mutfak turizmi ise doğal ortamında yetiştirilen ürünlerle hazırlanan yiyecek ve içecekleri tüketmeye yönelik otantik bir deneyim olarak tanımlanmaktadır. Dünden bugüne insanoğlu, yaşamını idame ettirebilmek için yaşadığı coğrafyanın kendilerine sunduğu kaynakları kullanarak birçok yiyecek ve içecek üretmiştir. Bu yiyecek ve içeceklerin göç, coğrafi keşif, ticaret veya turizm gibi etkenlerle diğer insanlar tarafından bilinirliği artmış, öyle ki günümüzde kendi yiyecek ve içecekleri ile harmanladıkları ve füzyon mutfak adı verilen yeni bir hal almıştır. Yüzyıllarca farklı toplum ve medeniyete ev sahipliği yapmış olan Anadolu toprakları ise iklimsel özellikleri, üç tarafının denizlerle çevrili olması, verimli toprakları, ayrıca kültürel çeşitliliğinin de etkisiyle zengin bir mutfak kültürüne sahip olmuştur. Osmanlıdan günümüze değin aktarılan yöresel mutfaklar geleneksel yöntemlerle yaşatılmaya devam edilmektedir.

Yapılan çalışmalar incelendiğinde, ülke veya bölgelerin özgün mutfak kültürünün turistlerin seyahatlerinde önemli bir unsur olduğu ve ülke ekonomilerine önemli katkılar sağladığ görülmektedir (Selwood, 2003; Karim, 2006; Mckrecher, 2008; Albayrak, 2013; Bekar ve Kıllıç). Öyle ki turizmden elde edilen gelirin \%30'unu gastronomi turizminin oluşturduğu Barcelona'nın her yıl 500'den fazla gastronomi aktivitesine ev sahipliği yaptığı, Barcelona'da her yıl dünyanın büyük gastronomi fuarlarından birinin gerçekleştirildiği ve bu fuara her sene yaklaşık 60 ülkeden 200 bin katılımcının geldiği bilinmektedir. Barcelona'nın turizm gelirinin yüzde 30'dan fazlasını yiyecek- içecek aktivitelerinden elde edilen gelirler oluşturmaktadır (Turizm Yazarları ve Gazetecileri Derneği, 2012). 2008 yılında Amerika Ulusal Ekonomi Araştırma (USDA- ERS) sonuçları, yerel yiyeceklerin hem doğrudan tüketiciye hem de restoran, otel gibi ara kanallara kazanımının 4,8 milyar dolar olduğunu göstermektedir (Low ve Vogel, 2011). Bu sonuçlar bize gastronomi turizminin dolayısıyla yerel yiyeceklerin bölge ve ülke ekonomisine, doğrudan ve dolaylı etkisinin milyar dolarlarla ifade edilebileceğini, ancak ülkemizde bu konuya Gaziantep, Hatay, Afyon gibi birkaç şehrimiz dışında yöresel yiyecek ve içeceklere eğilimin yeteri düzeyde olmadığını göstermektedir.

Bartın İli için turizm konulu çalışma/projeler incelendiğinde bu çalışmalarda daha çok ekoturizm, kırsal turizm konuları üzerinde yoğunlaşıldığı, destinasyonun gastronomik değerleri ile ilgili çalışmaların yöresel yemek tariflerini içeren kitapçıklarla sınırlı kaldığı gözlenmiştir. Bununla birlikte Batı Karadeniz Bölgesine gerçekleştirilen kültür turları için Bartın'ın önemli bir destinasyon olma özelliği taşıması, bu bölge için gerçekleştirilen seyahat organizasyonlarının tur programlarına kültür turlarını tamamlayıcı bir turizm çeşidi olarak gastro turların koyulmasının sağlanması, bir sonraki adım için ise tıpkı Hatay-Gaziantep, Şanlıurfa şehirleri ve bölgeleri gibi bölgenin gastro rotasının belirlenmesinde itici bir güç olabilmesi açısından bu çalışma için önem arz etmektedir. Bununla birlikte bu çalışma sonucunda Bartın'daki turizm işletme yöneticileri başta olmak üzere, konaklama ve yiyecek-içecek işletmelerinin yöresel tatlara daha fazla yer vermeleri, bu tatların İli ziyaret eden turistlerle paylaşılması, Bartın ili 
başta olmak üzere bölgede gastronomik bilinç oluşturma, geçmişten geleceğe bu lezzetlerin aktarılması hatta füzyon mutfak uygulamaları ile ülke ve dünya mutfaklarında yer almalarının sağlanması hedeflenmektedir.

Bu araştırmanın amacı, Bartın'da yiyecek-içecek deneyiminde bulunan yerli turistlerin yöresel yemek tüketim alışkanlıklarını ortaya koyarak yöresel yiyeceklere yönelik bilgi, davranış ve tutumlarını sayısal ifadelere dönüştürülüp analizler yapmaktır. Bu yolla Bartın mutfağının turistler tarafından bilinirliği tespit edilmeye çalışılmıştır. Gastronomi unsurlarının ve yöresel yiyeceklerin turist motivasyonuna ne kadar etki ettiğini belirlemek açısından da araştırma önem arz etmektedir.

\section{LITERATÜR İNCELEMESİ}

Bilindiği üzere destinasyonlar coğrafi konumları, sahip oldukları yeryüzü şekilleri, kültürel değerleri, eğlence hizmetleri gibi sundukları turistik çekicilikler ile kendine özgü ve tektir. Bu turistik çekiciler içerisinde değerlendirebileceğimiz ve günümüzde her ne kadar turistin ana seyahate çıkma sebebi olmasa bile gittiği destinasyonda mutlaka deneyimlemek isteyeceği en önemli seyahat motivasyonlarından birini sunulan yöreye özgü yiyecek ve içecekler oluşturmaktadır. Turistlerde bu keşfin en önemli belirleyicisi internet üzerinden yapılan paylaşımlar olmuştur. Bu paylaşımların kendi tarafından da deneyimlenme güdüsü artmış olan turist için gidilecek yerin tat ve lezzetleri seyahat sebep sıralamasında ilk siralara yerleşmiştir. Bu doğrultuda kişiyi bu seyahatlere iten nedenleri Mgonja vd., (2017) içi içe geçmiş üç halka ile açıklamışlarıdır.

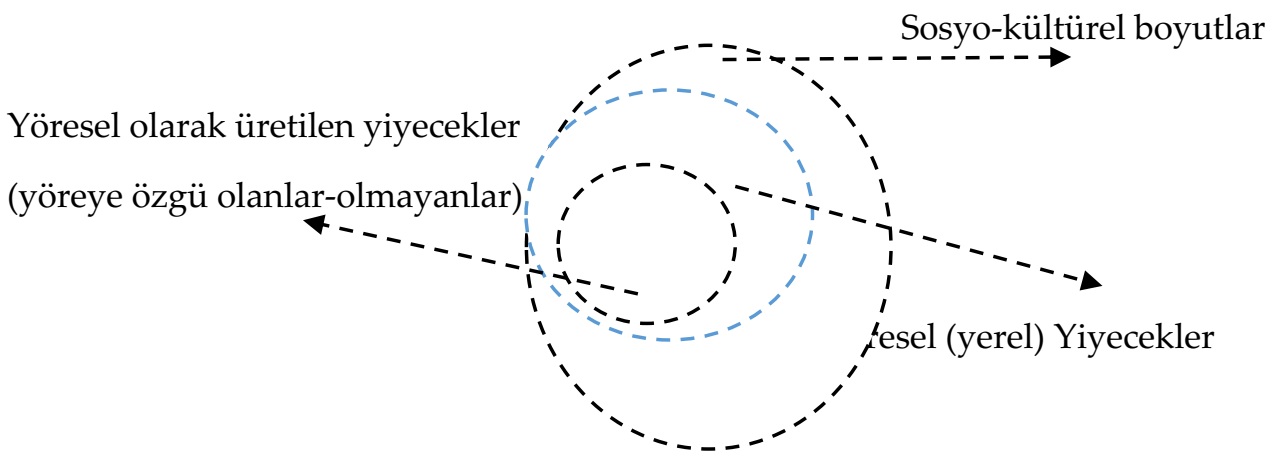

Şekil 1: Yöresel Yiyeceklerin Sosyo Kültürel Boyutları

Kaynakça: John vd., (2017:796-816).

Yöresel yiyecek ve içecekleri turizm sektör yönüyle önemli kılan sebeplerden birisi de kültürle olan ilişkisi ve kültürel kimlik oluşturmadaki etkisidir. Örneğin şampanya sadece Fransa'nın Champange bölgesinde yetiştirilen üzümlerden elde edilen şaraplara verilen isimdir ve buranın dışında üretilen şaraplar şampanya değil köpüklü şarap ismi ile üretilmekte ve pazarlanmaktadır. Bu bağlamda Champagne bölgesi tüm dünya tarafından bilinen ve şampanyalarıla tanınan turistik bir destinasyon haline gelmiştir. Bu durum bize turizm anlamında yöresel yiyecek ve içeceklerin katma değerlerinin, niş üretimleri sebebiyle çok daha fazla olduğu, bu nedenle daha fazla ödemeye hazır bir turist kitlesi ile bölgesel kalkınmaya katkı sağlanabileceğini göstermektedir. Bununla birlikte Avrupa'da özellikle Fransa ve İtalya, turizmdeki tanınırlıklarını ve ünlerini Bordeaux, Champagne, Toskana gibi bölgelerdeki yiyecek ve şaraplarına borçludur (Bessiere, 1998; Corigliano, 2002; Santich, 1999). 
John ve diğerlerine göre toplumun yaşam tarzı ile tükettiği yiyecekler birbirinden farklı düşünülemez. Her ne kadar günümüz insanının yiyecek ve içecek alışkanlıkları değişmiş olsa ve daha çok toplu yemek yeme yönlü bir eğilim gösterse de insanların yerele ve kendi topraklarında yetişen ürünlere yönelik yiyecekler olan ilgisi devam edecektir.

Bir destinasyonu seyahat sebebi olarak cazip hale getiren ve destinasyon imajı oluşmasına yardımcı olarak destinasyon seçimini etkileyen unsurlar; çevresel özellikler, eğlence olanakları, spor olanakları, kültürel çekicilik, gezilecek alanlar, sağlık olanakları, mutfak kültürü, konaklama imkanları, ulaşım olanakları ve alışveriş olanaklarıdır (Gürbüz,2005; Pekyaman,2008). Bu unsurlar arasında yer alan mutfak kültürünün turistlerin seçim sürecinde motivasyon yaratıcı ve cazibe unsuru olarak yer aldığı birçok çalışma ile ortaya konulmuştur (Maka, Lumbersa, Evesa ve Chang, 2012; Kim, Eves ve Scarles, 2013; Au ve Law, 2002).

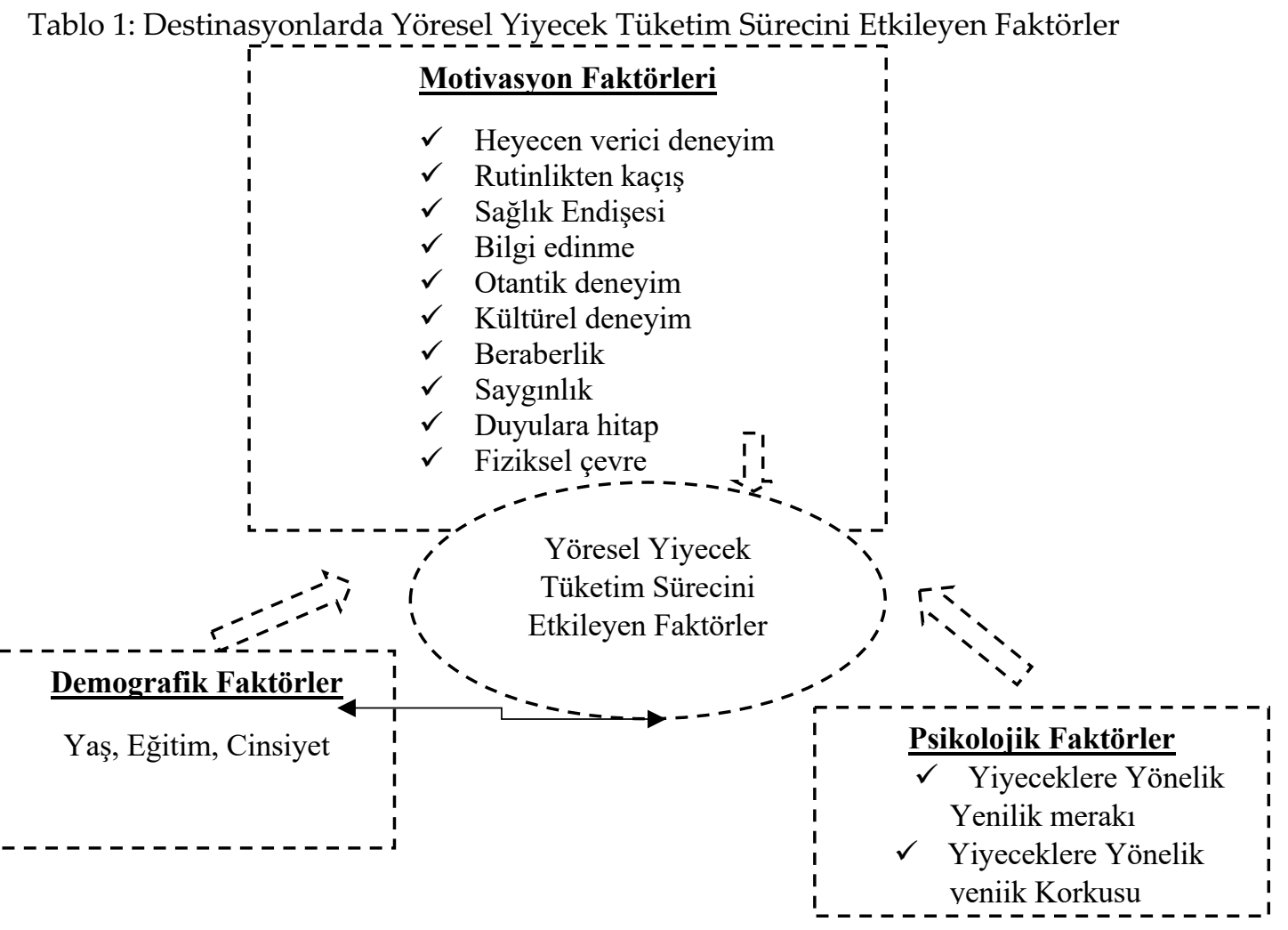

Kaynak: Kim, Eves ve Scarles, (2009:429

Yine UNWTO'nun hazırladığı Gıda (Yiyecek) Turizm Raporu (2016) için yapılan bir alan araştırmasında araştırmaya katılan organizasyonların büyük bir çoğunluğu (\%87) gastronominin bir destinasyonun marka olarak anılması ve imajının oluşturulmasında stratejik ve ayırıcı bir özelliğe sahip olduğunu ifade etmiştir.

Kim vd.'nin, 2009 yılında gerçekleştirdikleri "Destinasyonlarda Yöresel Yiyecek Tüketim Sürecini Etkileyen Faktörler" adlı çalışmada faktörler üç ayrı kısımla değerlendirmişlerdir. Bunlar motivasyon, demografik ve psikolojik faktörlerdir. Tablo 1 incelendiğinde özellikle heyecan verici deneyim, sağlik endişesi, bilgi edinme, otantik deneyim, kültürel deneyim, beraberlik, saygınlık, duyulara hitap ve fiziksel çevre, kişileri yöresel yiyecek ve içecekleri tüketme 
konusunda motive eden en önemli faktörler olarak karşımıza çıkmaktadır. UNWTO'nun hazırladığı Gıda Turizm Raporu (2016) için yapılan bir alan araştırmasına göre araştırmaya katılan organizasyonların büyük bir çoğunluğu (\%87) gastronominin bir destinasyonun marka olarak anılması ile stratejik ve ayırıcı bir özelliğe sahip olduğunu ifade etmişlerdir. Cevaplayıcılar ayrıca gastronominin turizmin gelişmesinde itici gücü oluşturduğunu 1 ila 10 arası kıyaslamada verdikleri 8.19 puanla ifade etmişlerdir. (UNWTO,2017:18).

Tablo 2: UNWTO, Gida Turizm Raporu

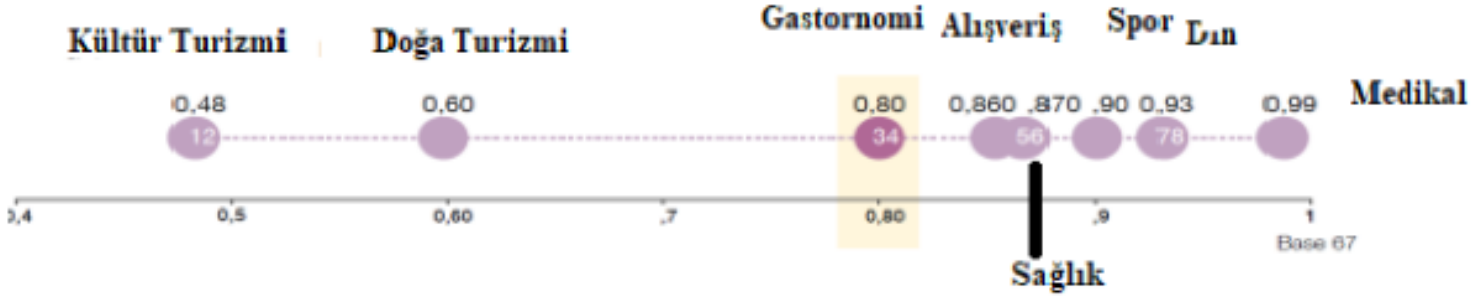

Yukarıdaki tablo bize araştırmaya katılan katılımcıların ziyaret sebeplerinin başında kültürel motivasyonun olduğunu, bunu destinasyonun sahip olduğu doğal güzelliklerin izlediği, gastronomi amaçlı ziyaretlerin seyahat nedenleri sıralamasında ise üçüncü sırada yer aldığını göstermektedir. Tablo bize ayrıca gastronomi turizmi amaçlı gerçekleştirilen seyahatlerin alışveriş- spor, dini ve medikal amaçlı yapılan ziyaretlerden daha fazla önem arz ettiğini de göstermektedir (UNWTO, 2017:17).

\section{YÖNTEM}

Bartın ile ilgili yapılan çalışmalar incelendiğinde, Bartın Turizmi ile ilgili genellikle eko turizm ağırlıklı çalışmalara yer verildiği görülmektedir. Bu çalışmanın hedefleri arasında Bartın'daki turizm işletme yöneticilerinin işletmelerinde yöresel tatlara daha fazla yer vermeleri, bu tanınan tatların İli ziyaret eden turistlerle paylaşılması, bölgede gastronomik bilinç oluşturma, geçmişten günümüze gelen bu lezzetlerin yaşatılması, hatta bu tatların füzyon mutfak uygulamaları ile ülke ve dünya mutfaklarında yer almasının sağlanması olduğu ifade edilebilir. Böylelikle Bartın'ın destinasyon imajı güçlenerek, İlin yalnızca ülke içerisinde bilinen bir destinasyon değil, tüm dünyada nokta destinasyon haline gelmesi için önemli bir adım olması açısından da önem arz etmektedir.

Bu bağlamda bu çalışma ile aşağıdaki sorulara yanıt aranmaya çalışılmaktadır:

1) Bartın'ı ziyaret eden yerli turistlerin yöresel yiyecekleri diğer yiyeceklere göre tercih etme durumu nedir? En çok hangi yiyecekleri beğenmektedirler?

2) Bartın' ı ziyaret eden yerli turistlerin yöresel yemekler hakkındaki bilgi düzeyleri nelerdir?

3) Yerli turistlerin Bartın mutfağını tanıma ve deneyimleme durumları ne düzeydedir?

4) Bartın mutfağ ile ilgili bilgiyi nereden edinmişlerdir?

5) Bartın mutfağı ile diğer mutfakları nasıl görmektedirler?

6) Bartın yemeklerini tekrar tatmak isterler mi?

7) Bartın mutfağını çevresindekilere tavsiye ederler mi?

8) Bartın mutfağına yönelik yöresel yiyecek deneyimi davranışsal niyetleri etkilemekte midir? 
9) Yöresel yiyecek deneyimi davranışsal niyetlere göre farklılık göstermekte midir?

\section{Araştırmanın Evren ve Örneklemi}

Bartın Turizm ve İl Müdürlüğü 2017 yılı verileri incelendiğinde Bartın'ı ziyaret eden turist sayısı 280441 kişidir. Bu sayının yaklaşık \%. 96'sını yerli turistler oluşturmuştur. Bu rakamlar bize bu çalışmanın yerli turistler üzerinden yürütüleceğini göstermektedir. Çalışmanın evrenini Bartın İlini özellikle de Amasra, İnkum ve Ulus ilçelerinin ziyaret eden yerli turistler oluşturacaktır. Çalışma evrenine uygun olarak destinasyona olan ziyaretlerin en yoğun olduğu yaz mevsiminde kolayda örnekleme yöntemi ile birebir anket yapılmış ve 2019 Mayıs ayında Bartın'ı ziyaret eden 397 yerli turiste ulaşılmıştır. Örneklem sayısı \%95 güvenirlik düzeyinde evreni istatistiki olarak temsil etmektedir (Kozak, 2015). Hazırlanan ölçek örneklem üzerinde uygulanmadan önce Turizm İşletmeciliği Bölümü öğrencileri anketörlerinin yüz yüze görüşme yöntemi ile bir pilot uygulama yapmış ve anketin geçerliliği ve güvenilirliğinin sağlanarak olası ifade hataları düzeltilmiş veya çalışmaya konulmamıştır.

\section{Verilerin Toplanması}

Verilerin toplanması için anket formu kullanılmıştır. Anket formu dört bölümden oluşmaktadır. Birinci bölümde Bartın mutfağı ile ilgili genel bilgi düzeyleri, ikinci bölümde Bartın mutfağında yer alan yöresel yiyeceklere yönelik davranışları, üçüncü bölümde yöresel yiyeceklere yönelik deneyim sonuçları ve son bölümde demografik bilgiler ve turistik davranışları ile ilgili sorular yer almaktadır. Anket formunun oluşturulmasında Cesur (2017), Ölmez (2017), Adongo (2015) davranışsal niyetler ile ilgili ifadeler Ölmez (2017), Liu ve Jang (2009)'ın kullandığı araştırmalardaki sorulardan faydalanılmıştır. Veriler 2019 Mayıs ayı içerisinde Bartın ilini ziyaret eden yerli turistlerle birebir görüşülerek elde edilmiştir.

\section{Verilerin Analizi}

Toplanan veriler SPSS 23 ve AMOS 22 programları yardımıyla analiz edilmiştir. Analiz olarak güvenirlik, frekans, korelasyon, T-testi, Anova, doğrulayıcı faktör analizi kullanılmıştır. Doğrulayıcı faktör analizi, gözlenen değişkenler ile bu gözlenen değişkenler aracılığıyla ölçülen yapı arasındaki ilişkiyi test etmek için yapılmıştır (Wetson ve Gore, 2006). Sekiz boyut ve toplam 25 maddeden oluşan yöresel yiyecek deneyimi ölçeğinin doğrulayıcı faktör analizi sonuçları modelin kabul edilebilir uyum indeksi değerine sahip olduğunu göstermektedir. Birinci düzey DFA sonucu uyum iyiliği değerleri $\left(x^{2}[62, N=397]=729,107 ; p<0.01 ; x 2 / s d=3,103\right.$; RMSEA= ,073; CFI=. 92; IFI= ,92, NFI= ,90) kabul edilebilir düzeydedir. Literatürde önerilen model ile veri uyumludur (Kline, 2011; Byrne, 2010). Davranışsal niyetler ölçeğinin üç maddesine yapılan faktör analizi sonuçlarına göre ölçeğin tek boyutta toplandı̆̆ görülmektedir. Açılanan varyans=83,472; öz değer=2,504; faktör yükleri ,90'ın üstünde çıkmıştır. Güvenirlik analizi için Cronbach Alpha hesaplanmıştır. Modelin boyutlarına ilişkin değerler 0,601 ile 0,941 arası değere sahiptir.

\section{BULGULAR}

Bartın İli için turizm konulu çalışma / projeler incelendiğinde bu çalışmalarda daha çok ekoturizm- kırsal, eko turizm konuları üzerinde yoğunlaşıldığı ancak ilin gastronomik değerleri ile ilgili çalışmaların yöresel yemek tariflerini içeren kitapçıklarla sınırlı kaldığı gözlenmiştir. 
Bununla birlikte Batı Karadeniz Bölgesine gerçekleştirilen kültür turları için Bartın'ın önemli bir destinasyon olma özelliği taşıması, bu bölge için gerçekleştirilen seyahat organizasyonlarının tur programlarına kültür turlarını tamamlayıcı bir turizm çeşidi olarak gastro turların koyulmasının sağlanması, bir sonraki adım için ise tıpkı Hatay-Gaziantep, Şanlıurfa şehirleri ve bölgeleri gibi bölgenin gastro-rotasının belirlenmesinde itici bir güç olabilmesi adına yapılan araştırmaya yönelik bulgular şöyledir:

Tablo 3: Bartın İli Yöresel Yiyecekler

\begin{tabular}{|l|l|l|l|}
\hline \multicolumn{3}{|l}{ ÜRÜN ADI } \\
\hline 1 & Amasra Çileği & 16 & Ovmaç Çorbası \\
\hline 2 & Amasra Salatası & 17 & Kıymalı Tarhana Çorbası \\
\hline 3 & Kabak Burması & 18 & Yoğurtlu Mancar \\
\hline 4 & Barın Gözlemesi & 19 & Ispıt \\
\hline 5 & Bartın Tatıı̈ Böreği & 20 & Maydanoz Köftesi \\
\hline 6 & İncir Dondurması & 21 & Pirinçli Bartın Mantısı \\
\hline 7 & Yumurtalı Ispıt & 22 & Bartın Gözlemesi \\
\hline 8 & Pirinçli Bartın Mantısı & 23 & Kabak Burması \\
\hline 9 & Kuru Yufka /Islama & 24 & Çimdik Çorbası \\
\hline 10 & Un (Kaşık) Helvası & 25 & Tavuklu Börek \\
\hline 11 & Bartın Köylü Manda Peyniri & 26 & Zırva \\
\hline 12 & Araka (Kabuklu Bezelye) Yemeği & 27 & Kaha Tatlısı \\
\hline 13 & Halışka & 28 & Ayvalı Yahni \\
\hline 14 & Pum Pum Çorbası & 29 & Beyaz Baklava \\
\hline 15 & Acı Mantar & 30 & Deli Oğlan Sarı̆̆ı \\
\hline
\end{tabular}

Yukarıdaki yiyecekler halen yerel halk tarafından pişirilmekte ve tüketilmektedir. Bu yemek ve yiyeceklerin bazıları bayram, düğün gibi özel günlerde hazırlanan yiyeceklerdir. Yiyeceklerin en temel özelliği ise hammaddelerinin yöreye özgü olması ve halen geleneksel pişirme yöntemleri kullanılarak pişirilmeleridir. Araştırmaya katılanların demografik bulguları Tablo 4'de gösterilmiştir.

Araştırmaya katılan turistlerin \%55'ini kadınlar oluşturmaktadır. Araştırmaya katılanların $\% 59,4^{\prime}$ ü bekardır. Araştırmaya en fazla \%35,3 oranla $20-25$ yaş aralığ ve $\% 24,5$ oranla $36-45$ yaş aralığındaki turistler katılmıştır. Gelir düzeyleri incelendiğinde $2000 \mathrm{TL}$ altı ve 3000-5000 TL arasında geliri olanların çoğunlukta olduğu görülmektedir. Araştırmaya genelde lise, önlisans ve lisans mezunu turistler katılmıştır. Yukarıdaki veriler incelendiğinde Bartın İline yönelik gerçekleştirilen seyahatlere karar vericileri \%55 oranında kadınlar olduğu, seyahat edenlerin $\% 59,9^{\prime}$ unun 20-45 yaş aralığında genç ve genç yetişkinlerden oluştuğu ve dolayısıyla gelir 
düzeylerinin ise $2000 \mathrm{TL}$ ve altı ila $3001 \mathrm{TL}-5000 \mathrm{TL}$ arası yoğunlaştığı görülmektedir. Çalışmaya katılanların \%62,9'u üniversite mezunu olduklarını ifade etmişlerdir.

Tablo 4. Demografik Bilgilerin Frekans Dağılımı

\begin{tabular}{|c|c|c|c|c|c|}
\hline Cinsiyet & $\mathbf{N}$ & $\%$ & Aylık Gelir & $\mathbf{N}$ & $\%$ \\
\hline Kadın & 221 & 55,7 & $\begin{array}{l}2000 \text { TL ve } \\
\text { alt1 }\end{array}$ & 152 & 38,3 \\
\hline Erkek & 176 & 44,3 & 2001-3000 TL & 66 & 16,6 \\
\hline $\begin{array}{l}\text { Medeni } \\
\text { Durum }\end{array}$ & $\mathbf{N}$ & $\%$ & $3001-5000 \mathrm{TL}$ & 129 & 32,5 \\
\hline Evli & 161 & 40,6 & $\begin{array}{l}5001 \text { TL ve } \\
\text { üstü }\end{array}$ & 50 & 12,6 \\
\hline Bekar & 236 & 59,4 & & & \\
\hline Yaş & $\mathbf{N}$ & $\%$ & Ĕ̆itim & $\mathbf{N}$ & $\%$ \\
\hline 15-19 & 24 & 6,0 & İlköğretim & 48 & 12,1 \\
\hline $20-25$ & 140 & 35,3 & Lise & 82 & 20,7 \\
\hline $26-35$ & 58 & 14,6 & Önlisans & 105 & 26,4 \\
\hline $36-45$ & 97 & 24,5 & Lisans & 145 & 36,5 \\
\hline $\begin{array}{ll}45 & \text { ve } \\
\text { üzeri } & \end{array}$ & 78 & 19,6 & Lisansüstü & 17 & 4,3 \\
\hline
\end{tabular}

Turistlere Bartın Mutfağı ile ilgili sorular sorulmuştur. Sorulara verilen cevapların frekans dağılımı tablo halinde aşağıda sunulmuştur.

Çalışmaya katılan yerli turistlerin \%60'ının Bartın mutfağı ile ilgili bilgi sahibi olmadığı, $\% 56$ 'sının Bartın yöresel yiyeceklerini restoranlarda tattı̆̆ı, Bartın mutfağı ile ilgili bilgiyi internet, eş-dost-akraba yoluyla edindikleri, Bartın yemeklerini tadanların \%56'sının memnun kaldığı, \%74'ünün Bartın yemeklerini tekrar tatmak istediği, \%81'inin Bartın'a tekrar tatile gelmeyi düşündüğü, \%43'lük kesimin ise tekrar ziyaret etme düşüncesinde Bartın mutfağının etkisi olduğunu, Bartın mutfağının diğer mutfaklara göre iyi gördükleri ve katılımcıların yarısını Bartın mutfağını tavsiye edeceğini belirtmişlerdir.

Katılımcıların Bartın Mutfağına yönelik yorumları incelendiğinde seyahat öncesi Bartın'ın yöresel yemekleri ile ilgili bir bilgilerinin olmadığı görülmektedir. Bilgi sahibi olanlar ise eş, dost, akrabalarından öğrendiklerini ifade etmişlerdir. Katılımcılar Bartın yemekleri hakkında genelde olumlu düşünceye sahiptir ancak Bartın'ı tekrar ziyaretlerinde Bartın yemeklerini deneyimlemenin ziyaret sebeplerinin önceliğini oluşturmamaktadır. 
Tablo 5. Bartın Mutfağı ile İlgili Tercihleri

\begin{tabular}{|c|c|c|c|c|c|}
\hline $\begin{array}{l}\text { Bartın mutfağ } 1 \text { ile ilgili daha önce } \\
\text { bilgi edindiniz mi? }\end{array}$ & $\mathbf{N}$ & $\%$ & $\begin{array}{l}\text { Bartın mutfağı ile ilgili bilgiyi } \\
\text { nereden edindiniz? }\end{array}$ & $\mathbf{N}$ & $\%$ \\
\hline Evet & 159 & 40,1 & Eş, dost, akraba & 110 & 27,7 \\
\hline Hayır & 238 & 59,9 & İnternette çevrimiçi yorum sitelerinden & 50 & 12,6 \\
\hline $\begin{array}{l}\text { Bartın yemeklerini ilk nerede } \\
\text { tattınız? }\end{array}$ & $\mathbf{N}$ & $\%$ & Kitap/broşürlerden & 8 & 2,0 \\
\hline Konakladığım tesiste & 51 & 12,8 & Gazete/dergilerden & 3 & 8 \\
\hline Restoranda & 225 & 56,7 & Sosyal medyadan & 22 & 5,5 \\
\hline Arkadaş/akraba evinde & 95 & 23,9 & TV/reklamlardan & 4 & 1,0 \\
\hline Diğer & 26 & 6,5 & Seyahat acentesinden & 16 & 4,0 \\
\hline $\begin{array}{l}\text { Bartın yemeklerini genel olarak } \\
\text { beğendiniz mi? }\end{array}$ & $\mathrm{N}$ & $\%$ & Diğer & 10 & 2,5 \\
\hline Evet & 223 & 56,2 & Toplam & 223 & 56,2 \\
\hline Hayır & 65 & 16,4 & $\begin{array}{l}\text { Bartın mutfağını diğer mutfaklarla } \\
\text { karşılaştırdığınızda ne düşünürsünüz? }\end{array}$ & $\mathbf{N}$ & $\%$ \\
\hline Kararsızım & 109 & 27,5 & Çok kötü & 12 & 3,0 \\
\hline $\begin{array}{lll}\text { Bartın } & \text { mutfağına } & \text { özgü } \\
\text { yemekleri } & \text { tekrar tatmak } & \text { ister } \\
\text { misiniz? } & & \end{array}$ & $\mathbf{N}$ & $\%$ & Kötü & 18 & 4,5 \\
\hline Evet & 296 & 74,6 & Ne iyi ne kötü & 205 & 51,6 \\
\hline Hayır & 101 & 25,4 & İyi & 137 & 34,5 \\
\hline $\begin{array}{l}\text { Bartın'a tekrar tatile gelir } \\
\text { misiniz? }\end{array}$ & $\mathbf{N}$ & $\%$ & Çok iyi & 25 & 6,3 \\
\hline Evet & 323 & 81,4 & $\begin{array}{l}\text { Bartın mutfağını çevrenizdekilere } \\
\text { tavsiye eder misiniz? }\end{array}$ & $\mathbf{N}$ & $\%$ \\
\hline Hayır & 36 & 9,1 & Evet & 199 & 50,1 \\
\hline Kararsızım & 38 & 9,6 & Hayır & 85 & 21,4 \\
\hline $\begin{array}{l}\text { Tekrar ziyaret düşüncenizde } \\
\text { Bartın mutfağının etkisi var mı? }\end{array}$ & $\mathbf{N}$ & $\%$ & Kararsızım & 113 & 28,5 \\
\hline Evet & 173 & 43,6 & & & \\
\hline Hayır & 224 & 56,4 & & & \\
\hline
\end{tabular}


Bartın'ı ziyaret eden yerli turistlerin Il'e yönelik tatil davranışlarının analizi Tablo 6'da görülmektedir. Bartın’ı tatile gelme faktörlerine bakıldığında Bartın mutfağı altıncı sırada gelmektedir. Bu sonuç bize İl'in yöresel yemek zenginliğine sahip olmasına rağmen mutfağ tanınmadığını göstermektedir. Tatil süresince yerli turistlerin en fazla balık yemeyi tercih ettikleri görülmektedir. Bu durumun Karadeniz'e yapılan seyahatlerin karakteristik özelliği olduğu söylenebilir. Katılımcıların \%27 oranı ile ikinci sırada Bartın'a özgü yemekleri tercih etmeleri ise yöre mutfağını sevdikleri şeklinde yorumlanabilir. Yörenin Ankara gibi metropol bir şehre yakın olması dolayısıyla turistlerin aile ve arkadaşları ile birlikte seyahate çıkma isteklerini arttırmaktadır.

Tablo 6. Bartın'a Yönelik Tatil Davranışları

\begin{tabular}{|c|c|c|c|c|c|}
\hline 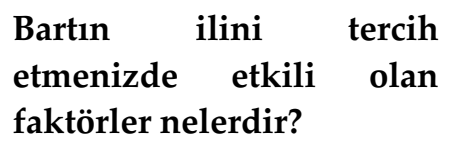 & $\mathbf{N}$ & $\%$ & $\begin{array}{l}\text { Tatil süresince genelde hangi } \\
\text { mutfağa özgü yemekleri tercih } \\
\text { edersiniz? }\end{array}$ & $\mathrm{N}$ & $\%$ \\
\hline Tatil fiyatının uygun oluşu & 116 & 29,2 & $\begin{array}{l}\text { Bartın mutfağına özgü } \\
\text { yemekleri }\end{array}$ & 107 & 27,0 \\
\hline Doğal güzellikleri görmek & 250 & 63,0 & Fastfood tarzı yemekleri & 42 & 10,6 \\
\hline Temiz bir çevre & 84 & 21,2 & $\begin{array}{l}\text { Kendi mutfağıma özgü } \\
\text { yemekleri }\end{array}$ & 43 & 10,8 \\
\hline $\begin{array}{l}\text { Bartın'ın tarihi ve kültürel } \\
\text { yerleri merak }\end{array}$ & 141 & 35,5 & $\begin{array}{l}\text { Pide, kebap, köfte tarzı } \\
\text { yemekleri }\end{array}$ & 57 & 14,4 \\
\hline $\begin{array}{l}\text { Bartın mutfağına özgü } \\
\text { yemekleri tatmak }\end{array}$ & 67 & 16,9 & Balık yemeyi tercih ederim & 145 & 36,5 \\
\hline $\begin{array}{l}\text { Bartın'ı güvenli bulduğum } \\
\text { için }\end{array}$ & 81 & 20,4 & Diğer & 3 & 8 \\
\hline Bartın'ı merak ettiğim için & 180 & 45,3 & Bartın'a kiminle geldiniz? & $\mathbf{N}$ & $\%$ \\
\hline Bartın halkını tanımak için & 46 & 11,6 & Yalnız & 56 & 14,1 \\
\hline Diğer & 42 & 10,6 & Ailemle & 150 & 37,8 \\
\hline $\begin{array}{l}\text { Bartın'a kaçıncı kez } \\
\text { geliyorsunuz? }\end{array}$ & $\mathbf{N}$ & $\%$ & Arkadaşlarımla & 168 & 42,3 \\
\hline İlk kez & 128 & 32,2 & Akrabalarımla & 16 & 4 \\
\hline 2-3 defa & 166 & 41,8 & Diğer & 7 & 1,8 \\
\hline 4-5 defa & 56 & 14,1 & & & \\
\hline $6 \mathrm{kez}$ ve üstü & 47 & 11,8 & & & \\
\hline
\end{tabular}


Tablo 7'de Bartın'ı ziyaret eden yerli turistlerin yöresel yiyecek deneyim ölçeği ve davranışsal niyetler arasındaki korelasyon analizi sonuçları görülmektedir. Korelasyon analizine göre, yöresel yiyecek deneyimi ile davranışsal niyetler arasında orta düzeyde ve pozitif yönlü bir ilişki görülmektedir. Analiz sonuçlarına göre yöresel yiyecek deneyimi arttıkça tekrar tatma ve tavsiye etme davranışı ve niyeti artmaktadır.

Tablo 7. Yöresel Yiyecekler Deneyimi Boyutları ve Davranışsal Niyetler Boyutu Aralarındaki Korelasyon Sonuçları

\begin{tabular}{|l|l|l|l|l|l|l|l|l|l|l|}
\hline Boyutlar & $\mathbf{1}$ & $\mathbf{2}$ & 3 & 4 & 5 & 6 & 7 & $\mathbf{8}$ & $\mathbf{9}$ & $\mathbf{1 0}$ \\
\hline $\begin{array}{l}\text { 1-Genel } \\
\text { Deneyim }\end{array}$ & 1 & & & & & & & & & \\
\hline 2-Hedonizm &, $667^{* *}$ & 1 & & & & & & & & \\
\hline 3-Yenilik &, $829^{* *}$ &, $662^{* *}$ & 1 & & & & & & & \\
\hline $\begin{array}{l}\text { 4-Yöresel } \\
\text { Kültür }\end{array}$ &, $754^{* *}$ &, $613^{* *}$ &, $663^{* *}$ & 1 & & & & & & \\
\hline 5-Tazelik &, $822^{* *}$ &, $490^{* *}$ &, $677^{* *}$ &, $626^{* *}$ & 1 & & & & & \\
\hline 6-Anlaml1lık &, $833^{* *}$ &, $484^{* *}$ &, $640^{* *}$ &, $595^{* *}$ &, $746^{* *}$ & 1 & & & & \\
\hline 7-Illgi &, $769^{* *}$ &, $334^{* *}$ &, $489^{* *}$ &, $427^{* *}$ &, $526^{* *}$ &, $602^{* *}$ & 1 & & & \\
\hline 8-Bilgi &, $749^{* *}$ &, $286^{* *}$ &, $464^{* *}$ &, $436^{* *}$ &, $478^{* *}$ &, $553^{* *}$ &, $752^{* *}$ & 1 & & \\
\hline $\begin{array}{l}\text { 9-Olumsuz } \\
\text { Deneyim }\end{array}$ &, $566^{* *}$ &, $138^{* *}$ &, $320^{* *}$ &, $192^{* *}$ &, $377^{* *}$ &, $389^{* *}$ &, $474^{* *}$ &, $509^{* *}$ & 1 & \\
\hline $\begin{array}{l}\text { 10 Davranıssal } \\
\text { Niyetler }\end{array}$ &, $568^{* *}$ &, $499^{* *}$ &, $495^{* *}$ &, $528^{* *}$ &, $444^{* *}$ &, $438^{* *}$ &, $385^{* *}$ &, $408^{* *}$ &, $208^{* *}$ & 1 \\
\hline
\end{tabular}

Araştırmaya katılan yerli turistlerin Bartın yemekleri ile ilgili bilgileri ve beğeni durumları çorba, sebze ve ot, ana yemek, hamur işleri ve tatlılar olarak ayrı ayrı tablolar halinde sunulmuştur.

Yerli turistlerin Bartın yemekleri beğeni durumları incelendiğinde; genel olarak bu yemekleri ya hiç duymadıkları ya da beğendiklerini ifade ettikleri görülmektedir. En fazla beğeni alan yemekler sırasıyla Amasra Salatası (262 beğeni), Kıymalı Tarhana Çorbası (196 beğeni), Bartın Gözlemesi (175 beğeni), Un helvası (168 beğeni) ve 157 beğeni ile Fasulye kavurmasıdır. Katılımcıların ismini hiç duymadıklarını söyledikleri yemekler ise; 1 . sırada Zırva (271 kişi), 2.sırada Kaha Tatlısı (263 kişi), Halışka (253 kişi), Karıştırma (239 kişi) ve Pum Pum Çorbası (237 kişi)'dır.

Yöresel yiyecek deneyiminin davranışsal niyetlere etkisini belirlemek için yapılan regresyon analizi yapılmıştır. Analiz sonuçları incelendiğinde çoklu regresyon analizi sonuçları istatistiksel olarak anlamlıdır. 
Tablo 8. Yerli Turistlerin Bartın Yemekleri Beğeni Durumları

\begin{tabular}{|c|c|c|c|c|}
\hline \multirow{2}{*}{ ANA YEMEKLER } & \multirow{2}{*}{ Duymadım } & \multicolumn{2}{|c|}{ Yedim } & \multirow{2}{*}{ Yemedim } \\
\hline & & Beğendim & Beğenmedim & \\
\hline Maydanoz Köftesi & 200 & 117 & 10 & 70 \\
\hline Ayvalı Yahni & 226 & 60 & 23 & 88 \\
\hline Karıştırma & 239 & 42 & 15 & 101 \\
\hline \multirow{2}{*}{ HAMUR İŞLERİ } & \multirow{2}{*}{ Duymadım } & \multicolumn{2}{|c|}{ Yedim } & \multirow{2}{*}{ Yemedim } \\
\hline & & Beğendim & Beğenmedim & \\
\hline Halışka & 253 & 64 & 16 & 64 \\
\hline Hamur Atması & 231 & 87 & 17 & 62 \\
\hline Pirinçli Bartın Mantısı & 209 & 92 & 20 & 76 \\
\hline Kuru Yufka/Islama & 193 & 124 & 15 & 65 \\
\hline Bartın Gözlemesi & 158 & 175 & 10 & 54 \\
\hline Kabak Burması & 223 & 72 & 21 & 81 \\
\hline Çimdik Çorbası & 233 & 59 & 20 & 85 \\
\hline \multirow[t]{2}{*}{ Tavuklu börek } & 191 & 127 & 16 & 63 \\
\hline & \multicolumn{3}{|c|}{ Yedim } & \multirow{2}{*}{ Yemedim } \\
\hline TATLILAR & Duymadım & Beğendim & Beğenmedim & \\
\hline Zirva & 271 & 48 & 11 & 67 \\
\hline Beyaz Baklava & 200 & 130 & 13 & 54 \\
\hline Un Helvası & 163 & 168 & 17 & 48 \\
\hline Bartın Tatlı Böreği & 213 & 87 & 17 & 80 \\
\hline Kaha Tatlısı & 263 & 42 & 16 & 76 \\
\hline İncir Dondurması & 212 & 103 & 11 & 71 \\
\hline Deli Oğlan Sarı̆̆1 & 243 & 50 & 12 & 92 \\
\hline \multirow{2}{*}{ ÇORBALAR } & & Yedim & & \multirow{2}{*}{ Yemedim } \\
\hline & Duymadım & Beğendim & Beğenmedim & \\
\hline
\end{tabular}




\begin{tabular}{lcccc}
\hline Kıymalı Tarhana Çorbası & 124 & 196 & 15 & 62 \\
\hline Pum Pum Çorbası & 237 & 50 & 17 & 93 \\
\hline Ovmaç Çorbası & 213 & 86 & 15 & 83 \\
\hline Kesme Çorbası & 183 & 126 & 11 & 77 \\
\hline Yufka Çorbası & 206 & 89 & 10 & 92 \\
\hline
\end{tabular}

Tablo 9. Yöresel Yiyecek Deneyiminin Davranışsal Niyetlere Etkisi, Regresyon Analizi

\begin{tabular}{|l|l|l|l|}
\hline Değişkenler & B & S.H. & $\beta$ \\
\hline Hedonizm &, 258 &, 062 &, $236^{* *}$ \\
\hline Yenilik &, 258 &, 081 &, 066 \\
\hline Yöresel Kültür &, 079 &, 072 &, $221^{* *}$ \\
\hline Tazelik &, 259 &, 069 &, 046 \\
\hline Anlamlılık &, 047 &, 076 &, 008 \\
\hline İlgi &, 009 &, 069 &, 024 \\
\hline Bilgi &, 025 &, 066 &, $173^{* *}$ \\
\hline Olumsuz Deneyim &, 175 &, 053 &,- 008 \\
\hline Sabit &, 634 &, 181 & \\
\hline
\end{tabular}

Not: $\mathrm{R} 2=0.37 ; \mathrm{F}(8-388)=28,461, \mathrm{p}<0.001,{ }^{* *} \mathrm{p}<0.01$

Regresyon kat sayısı $0.37^{\prime}$ dir. Bu sonuç davranışsal niyetlerin \%37'sini yöresel yiyecek deneyim tarafından açıklandığını gösterir. Ancak, tablodaki Beta katsayıları incelendiğinde, tüm bağımsız değişkenler regresyon modeline girildiğinde davranışsal niyetleri açıklamada hedonizm, yöresel kültür ve bilgi boyutlarının anlamlı katkısı vardır. Diğer boyutların anlamlı katkısı görülmemektedir. Bu sonuçlar bize yerli turistlerin sadece \%37'sinin Bartın ziyaret sebeplerini yöresel mutfak oluşturduğunu göstermektedir.

\section{SONUÇ VE ÖNERILLER}

2015 yılı Nisan ayında İspanya'da düzenlenen UNWTO (Birleşmiş Milletler Dünya Turizm Örgütü, I. Gıda (Yiyecek) Turizm Forumunda aşağıdaki sonuçlar ortaya çıkmıştır ki yapılan değerlendirmeler bize Gastronomi (Yiyecek) amaçlı yapılan seyahatlerin tüm dünya için önemi giderek artan bir turizm çeşidi olduğunu göstermektedir (UNWTO, 2017:27). Yiyecek Turizm Forumuna göre; 
1) Gıda (Yiyecek) Turizmi çeşitli sektörlerin işbirliği içerisinde çalı̧̧masına olanak sağlayan bir kesişme noktasıdır.

2) Gıda turizmi sürdürülebilirliğin bir taahhüdüdür. Gıda turizmi sayesinde çevresel, sosyokültürel ve ekonomik sürdürülebilirlik sağlanabilmektedir.

3) Gıda Turizmi küreselleşmeye karşı bir meydan okumadır. Destinasyonların tanıtımlarla global bilinirlikleri artabilir ancak elde edilecek tecrübe yereldir.

4) Gıda turizmi yerel ekonomiler için bir katalizör görevi görür. Gıda Turizmi yeni iş alanlarının ortaya çıkmasında ve yerel ekonominin geliştirilmesinde önemli bir turizm çeşididir. Gıda Turizmi ayrıca mevsimsel gelirlerin arttırılmasında da önemli katkı sağlar.

5) Gıda Turizmi koordineli çabalar bütünüdür. Bölgedeki paydaşların çabaları ile bölge ya da destinasyona bu turizm çeşidi yardımı ile artı değer kazandırılır.

6) Gıda Turizmi ile bölge/destinasyonda yetişen ürün/gıda/yemek ya da içeceklerin oluşum hikayelerinin ortaya çıkarılması sağlanır. Gıda Turistleri birer prosumer'dır. Yani üreten tüketicilerdir.

7) Gidilen her destinasyonun bir gastro potansiyeli vardır. Ancak destinasyonların amacı turistlere gastronominin de içerisinde olduğu bütünsel bir turizm tecrübesi yaşatmak olmalıdır. Destinasyonlar veya bölgeler ise bunu ancak sahip oldukları özgün yiyecek ve içecekler, sahip oldukları özgün manzara, kültür ve tarihleri ile turiste bütünsel bir deneyim kazandırmak kaydıyla gerçekleştirebilirler.

8) Destinasyon ya da bölgeler ancak kendi kimliğini ve özgünlügünü koruyabildiği takdirde küresel pazarlarda rekabetçi konuma gelebileceklerdir.

UNWTO I. Gıda (Yiyecek) Turizmi Forum Raporu incelendiğinde günümüzde destinasyonlar için Gıda Turizmi (Gastronomi), destinasyonun pazarlana bilirliğinde 3. sıradaki yeri ile önemli bir yer edindiği görülmektedir. Bu bağlamda bir yöre ya da bölgeye özgü yiyecek ve içecekler turistler için önemli bir çekicilik unsurunu oluşturmaktadır. Bunun için destinasyonların kendilerine has yiyecek ve içeceklerin turistler tarafından tadımının sağlanması, onların yöreye özgü tat ve lezzetleri deneyimlemeleri, bunun içinse öncelikle yöresel yiyecek ve içeceklerin geçmişten günümüze ve geleceğe aktarımının sağlanması bağlamında kendi hikâyeleri ile birlikte gün yüzüne çıarılarak envanterinin oluşturulması gerekmektedir.

Son yıllarda ülkemizde, özellikle sakin şehir (cittaslow) olma vasfı taşıyan destinasyonlarda ve coğrafi işaret alarak ürünlerini markalama çabası içerisinde olan yerlerde yöresel ürünlere olan farkındalık artmıştır. Bu bağlamda çalışmada, turizm faaliyetleri yalnızca kültür ve doğa turizmi ekseninde kalmış Batı Karedeniz Bölgesinin turistik şehirlerinden biri olan Bartın İli'ne gelen turistlerin yöresel yiyeceklere yönelik bakış açıları kolayda örneklem metodu kullanılarak değerlendirilmiştir. Çalışma 397 yerli turiste uygulanmış, anket yöntemiyle elde edilen verilerin SPSS 23 ve AMOS 22 programlarında analizi sağlanmıştır. Elde edilen sonuçlar değerlendirildiğinde;

- Bartın'daki yiyecek-içecek işletme yöneticileri başta olmak üzere tüm turizm işletme yöneticilerinin işletme mönülerinde yöresel tatlara daha fazla yer vermeleri gerektiği,

- İlde gastronominin önemine ilişkin etkinlik sayısının arttırılması gerektiği,

- Bartın İli başta olmak üzere bölgede gastronomik bilinç oluşturma, geçmişten geleceğe bu lezzetlerin aktarılması hatta füzyon mutfak uygulamaları ile ülke ve dünya mutfaklarında yer almaları konusunda çalışmalara başlanması gerektiği,

- Bartın Mutfağının yeterince tanıtımı yapılan bir mutfak olmadığı, Bartın Mutfağı ile ilgili yerel yiyecek- içecek işletme sayısının az olduğu ayrıca turizm işletme yöneticilerinin restoranlarında yöresel yiyeceklere daha fazla önem vermesi gerektiği, 
- Batı Karadeniz bölgesi kültür turlarını tamamlayıcı bir turizm çeşidi olarak gastro turların oluşturulması gerektiği,

- Yöresel yiyeceklerin İl turizmine sağlayacağı katkı konusunda farkındalığın öncelikle yöre halkında oluşması/oluşturulması gerektiği,

- Bartın Profesyonel Aş̧̧lar ve Pastacılar Derneği (BAPAPDER)'in İlin yöresel yemeklerinin tanıtımına ilişkin kamu kurum ve kuruluşlarıyla birlikte çalışması gerektiği,

- Batı Karadeniz Gastro- Rota çalışmalarına başlanılması gerektiği,

- İl Kültür ve Turizm Müdürlüğünün katıldığı fuarlarda Bartın Mutfağının tanıtımına daha fazla yer vermesi gerektiği,

- Büyük şehirlerde kurulan yöresel yemek stantlarında daha fazla yer alınması gerektiği,

- İlde bir Gastro çalıştayı düzenlenerek sonuçlarından yöreye tur gönderen seyahat acenteleri başta olmak üzere herkesin haberdar edilmesi gerektiği

- Bartın İli Somut Kültürel Miras Listesine Yöre mutfağının da eklenmesi gerektiği,

- İl'e gelen tur otobüsleri için şehrin girişine kurulacak Turizm Enformasyon Bürosunda yöresel yemeklerin turistlerin tadımına uygun alanlar oluşturulması gerektiği,

- Ev hanımlarının yöresel yemek ve ürünler yaparak bunları turistlere sunabilecekleri bir alana ihtiyaç duyulduğu ifade edilebilir.

$\mathrm{Bu}$ araştırma ile yerli turistlerin Bartın Mutfağı ile ilgili görüş ve düşüncelerinin neler olduğu tespit edilmeye çalışılmıştır. Özet olarak; Bartın Mutfağının yeterince tanıtımı yapılan bir mutfak olmadığı, Bartın Mutfağı ile ilgili yerel yiyecek- içecek işletmelerinin az olduğu, turizm işletme yöneticilerinin restoranlarında yöresel yiyeceklere daha fazla önem vermesi gerektiği söylenebilir. Batı Karadeniz bölgesi kültür turlarını tamamlayıcı bir turizm çeşidi olarak olarak gastro turların oluşturulabilmesi için yöresel yiyeceklere olan farkındalığın öncelikle yöre halkında oluşması/oluşturulması gerekmektedir. Konuya ilgi duyan araştırmacılar bundan sonraki süreçte Batı Karadeniz Bölgesinde yer alan diğer İlleri de kapsayacak bir çalışma yaparak çıan sonuçları karşılaştırabilir. Ayrıca Batı Karadeniz Gastro Rotasının oluşturulmasına katkı sağlayabilir.

\section{KAYNAKÇA}

$\mathrm{Au}, \mathrm{N}$., and Law, R. (2002). Categorical classification of tourism dining. Annals of Tourism Research, 29(3), 819-833.

Adongo, A. C., Anuga, S. W. and Dayour, F. (2015). Will they tell others to taste? International tourists' experience of Ghanaian Cuisines. Tourism Management Perspectives, 15, 57-64.

Bessiere, J. (1998). Local Development and Heritage: Traditional Food and Cuisine as Touristattractions in Rural Areas. Sociologia Ruralis, 21-34.

Bezirgan, M. ve Koç, F. (2014), Yerel Mutfakların Destinasyona Yönelik Aidiyet Oluşumuna Etkisi: Cunda Adası Örneği, Uluslararası Sosyal Araştırmalar Dergisi, 7(34):917-9287.

Byrne, B. M. (2001). Structural equation modeling with AMOS, EQS, and LISREL: Comparative approaches to testing for the factorial validity of a measuring instrument. International Journal of Testing, 1(1), 55-86. 
Cesur, E. (2017). Yerli turistlerin Doğu Karadeniz mutfağına ilişkin görüşleri. Balıkesir Üniversitesi Sosyal Bilimler Enstitüsü. Yayımlanmamış Yüksek Lisans Tezi.

Cesur, E. ve Avcıkurt, C. (2018). Kırsal Turizm Bölgelerini Ziyaret Eden Turistlerin Bölge Mutfağına Yönelik Görüşleri: Doğu Karadeniz Mutfağı. International Journal of Social and Economic Sciences, 8(1), 22-32.

Corigliano, M.A. (2002). The Route to Quality: Italian Gastronomy Networks in Operation. In A. Hjalager and G. Richards Tourism and Gastronomy. London: Routledge.

Doğu, F. A. (2009). Gıdaların Coğrafyası, 2. Geleneksel Gidalar Sempozyumu, 27-29 Mayıs 2009, s.1-4, Van.

Gürbüz, A. (2005). Kastamonu'ya Gelen Yerli Turist Profilini Belirlemeye Yönelik Bir Uygulama. Gazi Üniversitesi Ticaret ve Turizm Eğitim Fakültesi Dergisi, 2, 75- 92.

Hatipoğlu, A., Zengin, B.,Batman, O., ve Şengül, S. (2013). Yöresel Yemeklerin, Kırsal Turizm İşletmeleri Mönülerinde Kullanım Düzeyleri: Gelveri Örneği, Uluslararası Sosyal ve Ekonomik Bilimler Dergisi, 3(1), 6-11.

Mgonja, J. T., Backman, K. F., Backman, S. J., Moore, D. D. and Hallo, J. C. (2017). A structural model to assess international visitors' perceptions about local foods in Tanzania. Journal of Sustainable Tourism, 25(6), 796-816.

McKercher, B., Okumuş, F. and Okumuş, B. (2008), Food Tourism as a viable Market Segment: Its's all how you cook the numbers! Journal of Travel and Tourism Marketing, 25(2),137-148.

G.E. du Rand and E. Heath, (2006). Towards a Framework for Food Tourism as an Element of Destination Marketing, Current Issues in Tourism, 9(3), 206-234.

Kim, Y. G., Eves, A., and Scarles, C. (2009). Building a Model of Local Food Consumption onTrips and Holidays: A Grounded Theory Approach. International Journal of Hospitality Management, 28(3), 429.

Kim, Y. G., and Eves, A. (2012). Construction and Validation of a Scale to Measure Tourist Motivation to Consume Local Food. Tourism Management, 33(6), 1458-1467.

Kim, Y. G., Eves, A. and Scarles, C. (2013). Empirical verification of a conceptual model of local food consumption at a tourist destination. International Journal of Hospitality Management, 33, 484-489.

Kline, R.B. (2011). Principles and practice of structural equation modeling. New York: The Guilford Press.

Kozak, M. (2015). Bilimsel Araştırma: Tasarım, Yazım ve Yayım Teknikleri. 2. Baskı. Ankara: Detay Yayınları.

Liu, Y. and Jang, S.C. (2009). Perceptions of Chinese Restaurants in The U.S.: What Affects Customer Satisfaction and Behavioral Intentions? International Journal of Hospitality Management, 28(3), 338-348.

Low, S.A. and Vogel, S.J. (2011). Direct and Intermediated Marketing of Local Foods in The United States. USDA-ERS Economic Research Report 128.

Ölmez, Z. D. (2017). Gastronomi Turizminde Yerli Ziyaretçilerin Yöresel Yiyeceklere Yönelik Unutulmaz Deneyimlerinin Davranışsal Niyetleri Üzerine Etkisi: Seferihisar Örneği. Yayımlanmamış Yüksek Lisans Tezi. Balıkesir Üniversitesi Sosyal Bilimler Enstitüsü. 
Ölmez, Z. D., Zurnacı, N. and Bozok, D. (2017). Gastronomi Turizminde Yerli Ziyaretçilerin Yöresel Yemeklere Yönelik Tutum ve Davranışları: Seferihisar. İçinde: Gastronomi Turizmi Üzerine Araştırmalar Ed: Cevdet Avcıkurt, Düriye Bozok, Murat Doğdubay, Mehmet Sarıŏlan, Göksel Kemal Girgin. Ankara: Detay Yayıncilık.

Pekyaman, A. (2008). Turistik Satınalma Davranışında Destinasyon İmajının Rolü Afyonkarahisar Bölgesinde Bir Araştırma, Basılmamış Doktora Tezi, Afyon Kocatepe Üniversitesi Sosyal Bilimler Enstitüsü, Afyon.

Mak, A. H., Lumbers, M., Eves, A. and Chang, R. C. (2012). Factors influencing tourist food consumption. International Journal of Hospitality Management, 31(3), 928-936.

Sağır, A. (2012). Bir Yemek Sosyolojisi Denemesi Örneği Olarak Tokat Mutfağı, Turkish StudiesInternational Periodical for The Languages, Literature and History of Turkis hor Turkic, 7(4), 2675-2695.

Serçeoğlu, N. (2014). Yöre Halkının Öutfak Kültürünü Tanıma Durumunun Tespit Edilmesi: Erzurum İli Örneği, Journal of Tourism and Gastronomy Studies, 2(4),36-46.

Uslu A ve Kiper T. (2006). Turizmin Kültürel Miras Üzerine Etkileri: Beypazarı / Ankara Örneğinde Yerel Halkın Farkındalığı, Journal of Tekirdağ Agricultural Faculty, 3(3):305-314.

UNWTO, Gıda Turizm Raporu, (2017). http://www2.unwto.org/publication/unwto-am-reportvol-4-global-report-food-tourism

Turizm Yazarları ve Gazetecileri Derneği, (2012). http://www.tuyed.org.tr/gastronomi-turistiyemege-para-harciyor/ 